\title{
Life-world Knowledge and Scientific Knowledge: An Epistemological Rupture
}

\author{
Abdeljalil Métioui \\ Département de didactique \\ Université du Québec à Montréal, Canada \\ Louis Trudel \\ Faculté d'éducation \\ Université d'Ottawa, Canada
}

\begin{abstract}
The purpose of this paper is to highlight the epistemological rupture between the "lifeworld knowledge" and the "scientific knowledge." Their confrontations are essential in the teaching context.
\end{abstract}

Keywords: Life-world knowledge, scientific knowledge, continuity, discontinuity, epistemology, science teaching

\section{INTRODUCTION}

Science is a social activity like all other human activities. Its mode of production is influencing the socio-cultural environment and the political-economic context (Métioui \& Trudel, 2013; Solomon, 1993; Trudel \& Métioui, 2011). However, the content of scientific knowledge is the result of consensus-based approval in the scientific community. To this end, the Encyclopedia Universalis defines scientific content as being neutral that is, having neither national affiliation nor class membership (1980: 752). However, common knowledge is not universal, unlike scientific knowledge, and is the result of consensus among members of a given community.

The purpose of this paper is to highlight the epistemological discontinuity between the "common" language and the scientific language. For example, we will see that the concepts of the movement, force, time, speed, energy, heat and temperature do not have the same meanings in both languages.

We will also see that in a teaching-learning context one cannot acquire the "scientific language" without "confronting" it with the "common language" of the learners. For example, the second law of motion is accepted by scientists in its field of application, independently of the origins of the person applying it. Let us recall that this law developed in the 17 th century by the wellknown English physicist and mathematician Isaac Newton who asserted that the variation of the speed of a body, with respect to time (its acceleration), depends on the mass and the total force acting upon on it. Also, we have the Archimedes' principle, enunciated twenty-five centuries ago, which is always correct in the case of an incompressible object submerges in a fluid of constant density placed in a field of uniform gravitation.

This article reports on the common knowledge of children in different countries about scientific concepts such as heat, temperature, motion, force, speed, acceleration, energy, gravitation and electricity that are constructs in their environments. It also shows that this knowledge is in rupture with scientific knowledge. In this view, several researchers emphasize 
that common knowledge is an obstacle to learning science (Bachelard, 1975). This perspective appears to us to make a significant contribution to education in a multicultural context because of the importance of science in the world today and access to such knowledge.

\section{COMMON KNOWLEDGE (LIFE-WORLD KNOWLEDGE)}

The social sciences have shown that the concepts of life, natural phenomena, family, property, beliefs, freedom, democracy, and many others are socially constructed. Several factors influence these ideas, such as historical, geographic, economic, political and religious factors. Through these constructions, we find, on the one hand, a multiplicity of languages used, and, on the other hand, words commonly shared by the members of a given society.

Numerous studies in several countries showed that children' explanations about physical, chemical and biological phenomena are widely shared by their cultural community. For Astolfi (1992), this could be called a common knowledge that is deeply rooted in everyday experiences and has proved to be functional and operating in the social context from which it emerges.

An example of this common knowledge is provided by Tiberghien (1980) who described the pattern found in several studies of a pupil who had to decide if a block of ice covered with wool melts more rapidly than a block of ice covered with aluminum. The pupil expressed the opinion that the wool-covered block would melt faster because the wool keeps a person warm and consequently gives warmth.

Moreover, given the certainty that the block covered with aluminum melted first, the pupil was not ready to give up his convictions. This example is part of a body of research which reveals an enormous number of conceptions which, for children, disagree with accept scientific theories (e.g., Pfundt \& Duit, 1991). This example also illustrates the acknowledged fact that students do not readily pass from common knowledge to the scientific knowledge they are taught (Driver et al., 1994).

Also, research has shown that teaching science in schools does not work as expected (Roy, 1995; OECD, 2005). It is as if science education were missing certain conditions necessary for understanding scientific concepts. Astolfi (1992) explains the situation in terms of a superposition of knowledge, e.g. the scientific knowledge taught at school is "placated" on the common knowledge possessed by the pupil. Duit and Treagust (1995) cite two main reasons for this. On the one hand, students would be satisfied with their common language and would not see the value of scientist language. On the other hand, if the knowledge already acquired substantially determines the learning process, students see what the teacher (or textbook) presents through the lens of their common knowledge and, consequently, may not understand the concepts presented.

To this end, common knowledge origins from sensory, linguistic, cultural, or media or even academic factors (Duit \& Treagust, 1995) and constitute networks, which divers' elements are complementary and mutually reinforcing (Astolfi, 1992; Astolfi \& Develay, 1989).

Moreover, children's knowledge of natural phenomena may be different from one culture to another (Ross \& Sutton, 1982; Solomon, 1993). Duit (1981) cites the example of the concept of energy, which in the English language is strongly linked to living beings and especially to persons, whereas in the German language it is associated with electricity. Such differences may be relevant when seeking to clarify the learner's prior viewpoint on scientific concepts. 


\section{SCIENTIFIC KNOWLEDGE}

At the same time, there is scientific knowledge which, with the advent of the works of Galileo, Newton, Einstein, and many others, rejects in its explanations any presupposition, metaphysics, mysticism or folklore. It should be noted that the scientific theories developed by the Greeks and other ancient civilizations were speculative, but they played a decisive role in the development of science. Historians are unanimous that the Greeks were not concerned with practical considerations, which probably explains the lack of experimentation in their work. The approach used by contemporary scientists to construct their knowledge is a process of experimentation and modeling carried out within the framework of a given theory. Thus, the laws of motion developed by Newton, Albert Einstein's theory of special relativity, and Mendel's laws of genetics are unanimously accepted by the international scientific community.

On the other hand, scientific knowledge is a form of knowledge which, after Kuhn (1970), developed by "an increasingly detailed and precise understanding of nature" (p. 202). That supposes, according to Bachelard (1975), that it contradicts the common experience, that it deviates from the ordinary conditions of observation, that it opposes opinion and that it casts the variables in a dialectic approach by questioning facts, theories, and methods. From this point of view, the "common knowledge" is opposed to scientific knowledge. Bachelard stresses the problem of the rupture between common knowledge and scientific knowledge.

Indeed, research by, Agabra (1986), Driver and Russel (1982), Erickson (1980) and Strauss (1981), on several mainlands including Europe, Australia, South America, North America and Africa, attest to the epistemological discontinuity between the common knowledge of children and the explanatory models accepted by scientists.

In the light of this work, we present examples of common knowledge of children as well as the corresponding scientific knowledge.

\section{THE DISCONTINUITY BETWEEN COMMON KNOWLEDGE (LIFE-WORD KNOWLEDGE) AND SCIENTIFIC KNOWLEDGE: FORCE, SPEED, TIME AND ENERGY}

In the common language, the notion of force is associated with the field of the living, the physical effort to move objects as well as speed. Similarly, weight (gravitational force) is synonymous with mass. On the other hand, in scientific language, the notion of force is associated with acceleration. Studies in many countries have shown that common knowledge is an obstacle to the acquisition of scientific knowledge (e.g., Watts \& Zylbersztajn, 1981; Watts, 1983; McCloskey et al., 1980; Gunstone, 1984; Trowbridge \& McDermott, 1981; Gunstone \& White, 1981; Canal, 1986; Invernizzi et al., 1989; Métioui \& Baulu MacWillie, 2013; Mali \& Howe, 1979; Treagust et al., 1996). In table 1, we illustrate the epistemological rupture between life-word knowledge and scientific knowledge. 
Table 1. The epistemological rupture between the common knowledge (life-world knowledge) and the scientific knowledge about the notions of movement, force, time, speed and energy

\begin{tabular}{l|l}
\hline \multicolumn{1}{c}{ Common knowledge } & \multicolumn{1}{c}{ Scientific knowledge } \\
$\begin{array}{l}\text { Force is the cause of the movement of an } \\
\text { object: the more one pushes an object, the } \\
\text { further it goes. }\end{array}$ & $\begin{array}{l}\text { Force is the cause of the variation of the } \\
\text { motion of an object. }\end{array}$ \\
\hline $\begin{array}{l}\text { The weight of an object is its quantity of } \\
\text { matter (mass): do exercises to reduce your } \\
\text { weight. }\end{array}$ & Weight is the force of gravity. \\
\hline $\begin{array}{l}\text { Heavy objects fall faster than light objects: } \\
\text { a light bullet reaches the ground quicker } \\
\text { than a heavy one. }\end{array}$ & $\begin{array}{l}\text { In the absence of friction, the speed of an } \\
\text { object does not depend on its mass. }\end{array}$ \\
\hline $\begin{array}{l}\text { Acceleration is an increase in speed: to } \\
\text { accelerate means increasing its speed. }\end{array}$ & $\begin{array}{l}\text { Acceleration is a change per second, of } \\
\text { velocity. }\end{array}$ \\
$\begin{array}{l}\text { There is a linear relationship between } \\
\text { speed and distance or between speed and } \\
\text { time: do it fast, we have a long way to go; } \\
\text { hurry up, the film will start in five minutes. }\end{array}$ & $\begin{array}{l}\text { The velocity is the result of a division } \\
\text { operation between the distance, and the } \\
\text { time taken to traverse this distance. }\end{array}$ \\
$\begin{array}{l}\text { Time is related to events: when one gets } \\
\text { bored, time seems to be flowing very } \\
\text { slowly: }\end{array}$ & $\begin{array}{l}\text { Time is related to the study of periodic } \\
\text { phenomena. }\end{array}$ \\
\hline $\begin{array}{l}\text { Energy is a force: I eat cereals to have force. } \\
\text { Energy is a concept that was created to } \\
\text { associate electrical, mechanical, thermal, } \\
\text { phenomena, etc. Energy cannot be } \\
\text { measured directly. }\end{array}$ \\
\hline
\end{tabular}

Many of these conceptions are strikingly like those that found at certain stages of the evolution of scientific concepts in the history of science. Force as the cause of movement in Aristotle theory (e.g., Métioui \& Trudel, 2017).

\section{THE DISCONTINUITY BETWEEN COMMON KNOWLEDGE (LIFE-WORD KNOWLEDGE) AND SCIENTIFIC KNOWLEDGE: HEAT, TEMPERATURE AND ENERGY}

Students' conceptions of heat and temperature are found in many studies (e.g., Agabra, 1986; Driver \& Russel, 1982; Erickson, 1980; Tiberghien, 1980). In everyday language, heat is described as a substance that possesses properties attributed to material objects. However, in scientific knowledge, heat is described as a form of energy associated with the movement of bodies. In table 2 , we illustrate the epistemological break between common knowledge and scientific knowledge. 
Table 2. Discontinuity between common knowledge (life-word knowledge) and scientific knowledge about the notions of heat and temperature

\begin{tabular}{l|l}
\hline \multicolumn{1}{c}{ Common knowledge } & \multicolumn{1}{c}{ Scientific knowledge } \\
\hline $\begin{array}{l}\text { The sun warms us up. } \\
\text { The more a liquid is heated, the higher its } \\
\text { temperature. }\end{array}$ & $\begin{array}{l}\text { Notions of heat and temperature are } \\
\text { not equivalent. }\end{array}$ \\
$\begin{array}{l}\text { Heat passes through objects such as door } \\
\text { or walls. }\end{array}$ & $\begin{array}{l}\text { Heat is the energy transferred during } \\
\text { In a room, not all objects are at the same } \\
\text { temperature. For example, a metal object } \\
\text { is colder than a non-metallic object. }\end{array}$ \\
$\begin{array}{l}\text { Marble and iron are cold. } \\
\text { On the other hand, a wool dress is warm. }\end{array}$ \\
$\begin{array}{l}\text { Heat is when you're hot; it's hot. } \\
\text { Polystyrene does not allow heat to enter. }\end{array}$ \\
$\begin{array}{l}\text { A thermos keeps the heat. } \\
\text { The temperature of the hot water melts the }\end{array}$
\end{tabular}

Many of these conceptions are strikingly like those that found at certain stages in the evolution of scientific notions in the history of science. The theory of caloric which in the eighteenth century attributed heat to the characteristics of a material substance (Driver et al., 1985).

\section{THE DISCONTINUITY BETWEEN COMMON KNOWLEDGE (LIFE-WORD KNOWLEDGE) AND SCIENTIFIC KNOWLEDGE: CURRENT, VOLTAGE AND ELECTRICAL POWER}

Students' conceptions of electricity are found in many studies (e.g., Bilal \& Erol, 2009; Brna, 1988; Closset, 1983; Dupin \& Johsua, 1984; Métioui et al., 2016). In common language, we use everyday expressions related to electricity and electrical circuits, such as opening or closing the light, consumption of current (or power), consumption of the battery, current and voltage, the force of the current (or energy), etc. In Table 3, we will see that these expressions are erroneous compared to those used in the scientific language. Numerous studies show that the common language related to electricity is a significant obstacle to the acquisition of scientific knowledge, despite the fact that it is spread over several years (Closset, 1983; Métioui et al., 2016).

Table 3. Discontinuity between common knowledge (life-word knowledge) and scientific knowledge about the notions of voltage and electrical current

\begin{tabular}{l|l}
\hline Common knowledge (Life-world knowledge) & \multicolumn{1}{c}{ Scientific knowledge } \\
\hline $\begin{array}{l}\text { The battery is a constant current source. } \\
\text { There is electricity and wires in a battery. }\end{array}$ & The battery is a variable current source. \\
$\begin{array}{l}\text { There either energy, a force or volts in a } \\
\text { battery. }\end{array}$ & $\begin{array}{l}\text { The cell consists of two electrodes and an } \\
\text { ionic (or acidic) solution. }\end{array}$ \\
\hline $\begin{array}{l}\text { Voltage is the force of the electric current. } \\
\begin{array}{l}\text { The words current and voltage are } \\
\text { essentially interchangeable: they represent } \\
\text { elightly different aspects of the same }\end{array}\end{array}$ & $\begin{array}{l}\text { The voltage (potential difference) is the } \\
\text { difference of potential energy per unit } \\
\text { charge; currents reflects the net flow of } \\
\text { electrical charges. }\end{array}$ \\
\hline
\end{tabular}




\section{LIMIT OF THE PARALLELISM}

Although such parallelism is limited, he suggests that, following Piaget (1967) and Bachelard (1968), there would be, behind common knowledge, epistemological characteristics which must be taken into account to make learning meaningful for science students. Common knowledge and scientific knowledge are very different experience as indicated by a comparative epistemological analysis made by Solomon (1993) (see Table 3). For this author, common knowledge is characterized by social exchanges based on mutual understanding, a polysemic use of words, dependency on the cultural group as well as the physical and emotional context, a tolerance of contradictions, and a system of social knowledge.

In contrast, scientific knowledge is characterized by a debate that accentuates differences, makes precise use of concepts whose definitions are unambiguous, uses notions whose meaning is symbolic and abstracted from situations, which requires a very rigorous logic based on a knowledge system that is not socialized in the school environment.

Van Aalst (1989), states that common knowledge relies on an intuitive framework of interpretation, while scientific knowledge is based on a structure of reflective description fueled by questioning. One can, therefore, understand the magnitude of the conceptual shift between common experience and scientific knowledge.

Table 4. Two worlds of knowledge after Solomon (pages 92-93, 1993)

\begin{tabular}{l|l}
\hline $\begin{array}{l}\text { Common knowledge (Life-world knowledge) } \\
\text { understanding and agreement. }\end{array}$ & \multicolumn{1}{c}{ Scientific knowledge } \\
$\begin{array}{l}\text { Words used have multiple meanings which } \\
\text { are not defined but negotiated socially. }\end{array}$ & $\begin{array}{l}\text { The aim of debate is to sharpen differences } \\
\text { and to confirm or refute rival opinions. } \\
\text { defined for exact use. }\end{array}$ \\
$\begin{array}{l}\text { Meanings are dependent on the cultural } \\
\text { group and on the physical or affective } \\
\text { context. }\end{array}$ & $\begin{array}{l}\text { Concept meanings are symbolic and } \\
\text { abstracted from any particular situation. }\end{array}$ \\
$\begin{array}{l}\text { Apparent contradictions are tolerated. No } \\
\text { logical method is thought to be needed. }\end{array}$ & $\begin{array}{l}\text { A tight logical network of concepts and } \\
\text { theories is claimed. }\end{array}$ \\
$\begin{array}{l}\text { This knowledge system is well socialized } \\
\text { daily use with familiar people. }\end{array}$ & $\begin{array}{l}\text { This knowledge is not well socialized since } \\
\text { its mods are rarely used and then only } \\
\text { by teachers outside the peer group. }\end{array}$ \\
\hline
\end{tabular}

\section{CONCLUSION AND DIDACTICAL IMPACT}

In the light of the differences between common knowledge and scientific knowledge, teaching science is a significant challenge for teachers. Driver et al. (1994) argue that scientist ideas and concepts that result from the scientific activity are not capable of being discovered by individuals through non-systematic research. Instead, science learning involves being introduced to the ideas and practices of the scientific community so that these ideas and concepts become meaningful on an individual level. The role of the science educator is to mediate scientific knowledge for learners who help them to overcome, in the view of Bachelard (1968), the epistemological obstacles linked to common knowledge deeply rooted in the broader experience of life outside of school.

Today we speak of construction of knowledge as opposed to transmission of knowledge for the acquisition of scientific concepts (Driver et al., 1994, Von Glasersfeld, 1994; Treagust et al., 1996). Knowledge of the common knowledge with which children approach science learning is considered of great pedagogical value. For this reason, teachers may benefit from being trained in various cultural modalities of this knowledge to open up to students of different cultural 
backgrounds and to understand the factors involved in their learning of the sciences. Not identical from one country to another, from one culture to another, or even in a multicultural context, the common knowledge of children can bring out epistemological peculiarities that must be overcome to have access scientific knowledge. A better knowledge of this prior knowledge would allow teachers to target pedagogical strategies that will help children overcome barriers to discover the differences between common knowledge and scientific knowledge.

\section{References}

Agabra, J., 1986. Les échanges thermiques. ASTER, 2, 1-41.

Astolfi, J.-P., 1992. L'école pour apprendre. Paris, ESF éditeur.

Astolfi, J.-P. and Develay, M., 1989. La didactique des sciences. Paris, Presses Universitaires de France.

Bachelard, G., 1975. La formation de l'esprit scientifique. Paris, Librairie philosophique J. Vrin, 9e édition.

Bachelard, G., 1968. The Philosophy of No. A philosophy of the new scientific mind. New York, The Orion Press.

Bilal, E. and Erol, M., 2009. Investigating students' conceptions of some electricity concepts. Latin American Journal for Physics Education, 3, 2, 193-201.

Brna, P., 1988. Confronting misconceptions in the domain of simple electric circuits. Instructional Science, 17, 29. 55 .

Canal, J.-L., 1986. La vitesse au cours moyen. ASTER, 2, 133-166.

Driver, R., Asoko, H., Leach, J., Mortimer, E. and Scott, P., 1994. Constructing Scientific Knowledge in the Classroom. Educational Researcher, 5-12.

Driver, R., Guesne, E. and Tiberghien, A., 1985. Some features of children's ideas and their implications for teaching. In R. Driver, E. Guesne et A. Tiberghien (Editors), Children's Ideas in Science, England, Open University Press, Milton Keynes, 193-201.

Driver, R. and Russel, T., 1982. An Investigation of the Ideas of Heat, Temperature, and Change of State of Children aged between 8 and 14 years. Unpublished manuscript, England, University of Leeds.

Duit, R., 1981. Learning Energy Concept in School - Empirical Results from the Philippines and West Germany. Physics Education, 19, 59-66.

Duit, R. and Treagust, D.F., 1995. Students' Conceptions and Constructivist Teaching Approaches. In Improving Science Education, B. J. Fraser and H. J. Walberg (Editors), Chicago, University of Chicago Press, 46-69.

Dupin, J.J. and Johsua, S., 1987. Conceptions of French pupils concerning electric circuits: Structure and evolution. Journal of Research in Science Teaching, 24, 9, 791-806.

Encyclopoedia Universalis, 1980. 14.

Erickson, G., 1980. Children's Viewpoint of Heat: A Second Look. Science Education, 64, 323-336.

Gunstone, R.F., 1984. Circular Motion: Some Pre-Instructional Alternative Frameworks. Research in Science Education, 14, 125-35.

Gunstone, R.F. and White R.T., 1981. Understanding of Gravity. Science Education, 65, 219-299.

Invernizzi, S., Marioni, C. and Sabatini, P., 1989. Mouvement et vitesse au cours élémentaire. ASTER, 8, $211-223$.

Kuhn, T.S., 1970. The structure of scientific revolutions (2nd ed.). Chicago, IL,: University of Chicago Press.

Mali, G.B. and Howe, A., 1979. Development of Earth and Gravity Concepts among Nepali Children. Science Education, 63, 5, 685-691.

McCloskey, M., Carmazza, A. and Green, B., 1980. Curvilinear Motion in the Absence of External Forces: Naïve Beliefs about Motion of Objects. Science, 210, 1139-1141.

Métioui, A. and Baulu-MacWillie, M., 2013. Children's Beliefs about the Concepts of Distance, Time and Speed. International Journal of Education, Learning and Development, 1, 2, 24-38. 
Métioui, A., Baulu-Mac Willie, M. and Trudel, L., 2016. Conceptions of pupils of the primary on the topic of an electric circuit in three countries (Canada, France and Morocco). European Journal of Science and Mathematics, 4, 4, 469-476.

Métioui, A. and Trudel, L., 2013. Conception of Quebec Students in Teacher Education Regarding the Construction Modes of Science Knowledge. American Journal of Educational Research, 1, 8, 319-326.

Métioui, A. and Trudel, L., 2017. Misconceptions and History of Science in Science-Student Education: ForceGravity and Motion. International Journal of Technical Research and Applications, 5, 1, 88-94.

OECD, 2005. Declining Student Enrolment in Science \& Technology: Is It Real? What Are the Causes? What Can Be Done? Amsterdam, Koepelkerk Convention Centre.

Pfundt, H. and Duit, R., 1991. Bibliography-Students Alternative Frameworks and Science Education Germany, Institute for Science Education, University of Kiel.

Piaget, J., 1967. Logique et connaissance scientifique, Paris, Éditions Gallimard.

Ross, K. and Sutton, C., 1982. Concept Profiles and the Cultural Context. European Journal of Science Education, 4, 311-323.

Roy, J.A., 1995. Représentations du rôle de l'enseignant des sciences telle qu'elle émerge de recherches qualitatives publiées de 1983 à 1993 dans les revues Science Education et Journal of Research in Science Teaching. Revue des sciences de l'éducation, 21, 2, 241-262.

Shipstone, D.M., 1984. A study of children' understanding of electricity in simple DC circuits. European Journal of Science Education, 6,185-198.

Solomon, J., 1993. The Social Construction of Children's Scientific Knowledge. In P. J. Black et A. M. Lucas (dir.), Children's Informal Ideas in Science, UK, Routledge.

Strauss, S., 1981. Cognitive Development in School and Out. Cognition, 10, 242-245.

Tiberghien, A., 1980. Modes and Conditions of Learning - An Example: The Learning of Some Aspects of the Concept of Heat. In Cognitive Development Research in Science and Mathematics: Proceedings of an International Seminar, W. Fred Archenhold, Rosalind Driver, Anthony Orton, and Colin Wood-Robinson (Directors), Leeds, UK, University of Leeds, 288-309.

Treagust, D.F., Duit, R. and Fraser, B.J., 1996. Overview: Research on Students' Preinstructional Conceptions - The Driving Force for Improving Teaching and Learning in Science and Mathematics. In D. F. Treagust, R. Duit et B. J. Fraser (dir.), Improving Teaching and Learning in Science and Mathematics, Teachers College Press, New York, Columbia University, 1-14.

Trudel, L. and Métioui, A., 2011. Diagnostic of Attitudes towards Science Hel by Pre-Service Future Science Teachers. The International Journal of Science in Society, 2, 4, 63-83.

Trowbridge, D. and McDermott, L., 1981. Investigation of Student Understanding of the Concept of Acceleration in One Dimension. American Journal of Physics, 49, 242-253.

Van Aalst, H.F., 1989. Aboutir à des propositions pour l'enseignement des sciences. In A. Giordan, A. Henriques et V. Bang, Psychologie génétique et didactique des sciences, Peter Lang Éditeur, 257-273.

Von Glaserfeld, E., 1994. Pourquoi le constructivisme doit-il être radical ? Revue des sciences de l'éducation, 20, 1, 21-27.

Watts, D.M., 1983. A Study of School Children's Alternative Frameworks of the Concept of force. European Journal of Science Education, 5, 2, 217-230.

Watts, D.M. and Zylbersztajn, A., 1981. A Survey of Some Children's Ideas about Force. Physics Education, 15, 360365 . 